\title{
Ultrasound and MRI features of lipomatosis of the median nerve: A case study
}

\author{
Median sinir lipomatozisinin ultrason ve MR görüntüleme özellikleri
}

Cemal Aydin GUNDOGMUS, Onur BUGDAYCI, Mustafa Erkin ARIBAL

\begin{abstract}
We present a case of a 10 year-old girl with slowly enlarging, painless mass at the volar aspect of her left hand. The lesion had been present since infancy. Diagnosis was lipomatosis of the median nerve which is a very rare, benign tumor involving peripheral nerves. Magnetic resonance imaging (MRI) and ultrasound (US) features of this lesion are discussed.
\end{abstract}

Keywords: Median nerve lipomatosis, Fibrolipomatous hamartoma, Congenital tumor, Peripheral nerve

Cemal Aydin Gundogmus ( ( ), Onur Bugdayci

Department of Radiology, School of Medicine, Marmara University, Pendik, Istanbul, Turkey

e-mail:cagundogmus@gmail.com

Mustafa Erkin Aribal

Department of Radiology, School of Medicine, Aclbadem Mehmet Ali Aydinlar University, Acıbadem, Istanbul, Turkey
ÖZ

$\mathrm{Bu}$ vaka bildiriminde, sol el volar yüzde, infant döneminden beri olan, yavaş büyüyen, ağrısız şişlik şikayeti olan 10 yaşında bir kız çocuğu sunulmaktadır. Tanı, periferik sinirleri tutan çok nadir, benign bir tümör olan median sinirin lipomatozisi idi. Yazıda median sinir lipomatozisinin magnetik rezonans görüntü (MRG) ve ultrason (US) özellikleri tartış1ld.

Anahtar kelimeler: Median sinir lipomatozisi, Fibrolipomatöz hamartom, Konjenital tümör, Periferik sinir

\section{Introduction}

Lipomatosis of the peripheral nerves are very rare congenital lesions. The median nerve is the most commonly affected nerve, mostly at the level of the wrist. Magnetic resonance imaging (MRI) is diagnostic for this entity and most of the case reports (less than 100 so far) put emphasis on its MRI features [1]. Ultrasound (US), as well, provides very valuable information. In this report, we discussed US imaging features of lipomatosis of the median nerve with MRI correlation.

\section{Case Report}

A 10-year-old girl admitted to our orthopedics clinic with complaints of swelling at the volar aspect of her left (nondominant) hand. Her history revealed that it had been present since infancy and had grown slowly. She did not have complaints of pain, sensorial loss or muscle weakness. There were no signs of carpal tunnel syndrome.

Physical examination revealed an elastic, soft, non-tender, $4 \times 3$ $\mathrm{cm}$ mass at the central region of her left proximal palmar region. The mass was not extending to the wrist. Macrodactyly was not present. No thenar atrophy was noticed. Sensorial alteration was not noted. Both Phalen's and Tinel's signs were negative. 
Results of baseline laboratory tests were in normal ranges. Intravenous (IV) contrast enhanced MRI of her left hand was requested.

The MRI examination revealed a $57 \times 32 \mathrm{~mm}$ lesion, originating from median nerve at the volar aspect of the left hand. The lesion was isointense to fat on all sequences and surrounding nerve fibers (the so called "co-axial cable like" or "spaghetti like" appearance) (Figure 1a,b,c). The lesion did not enhance with IV contrast (Figure 2a,b). We performed US examination to determine its proximal extent.

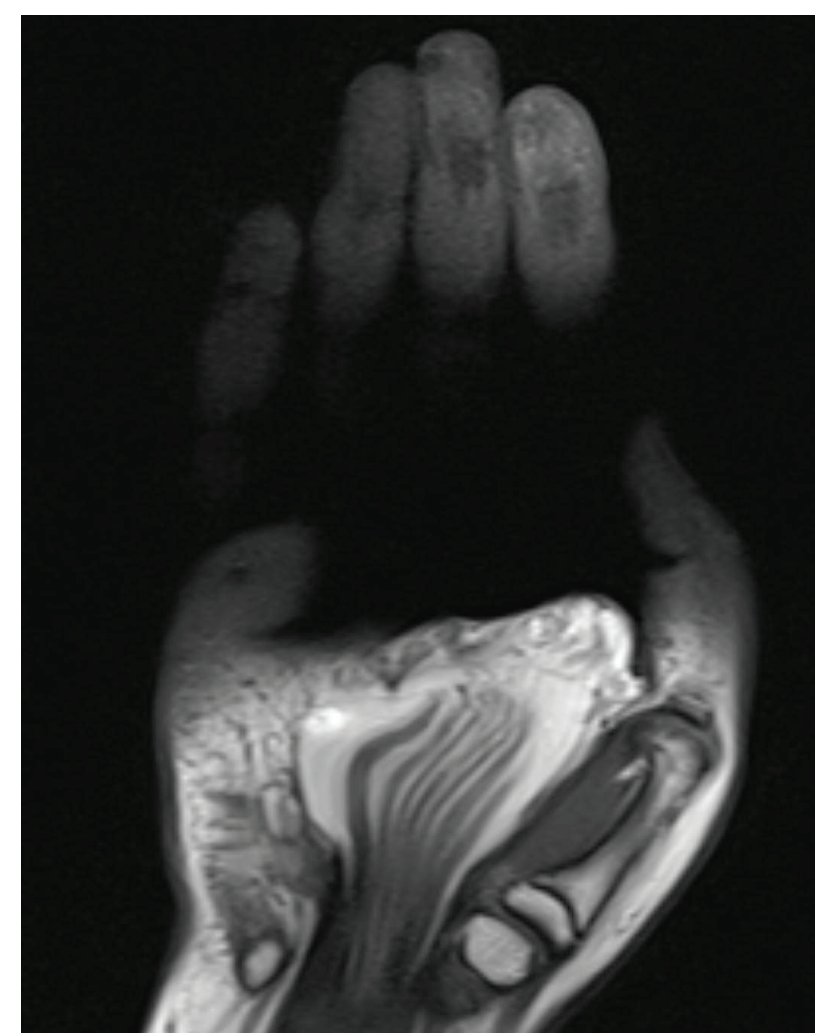

Figure 1a. T1 TSE coronal images show spaghetti like and coaxial cable like appearences.

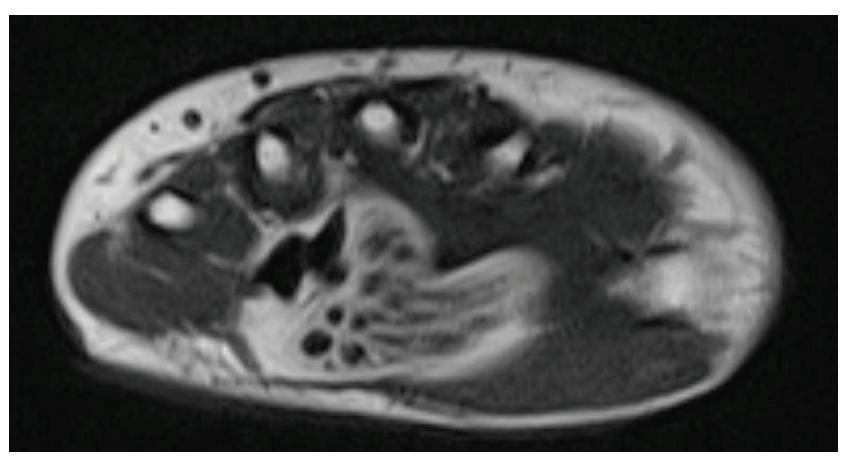

Figure 1b. T1 TSE axial images show spaghetti like and co-axial cable like appearences.

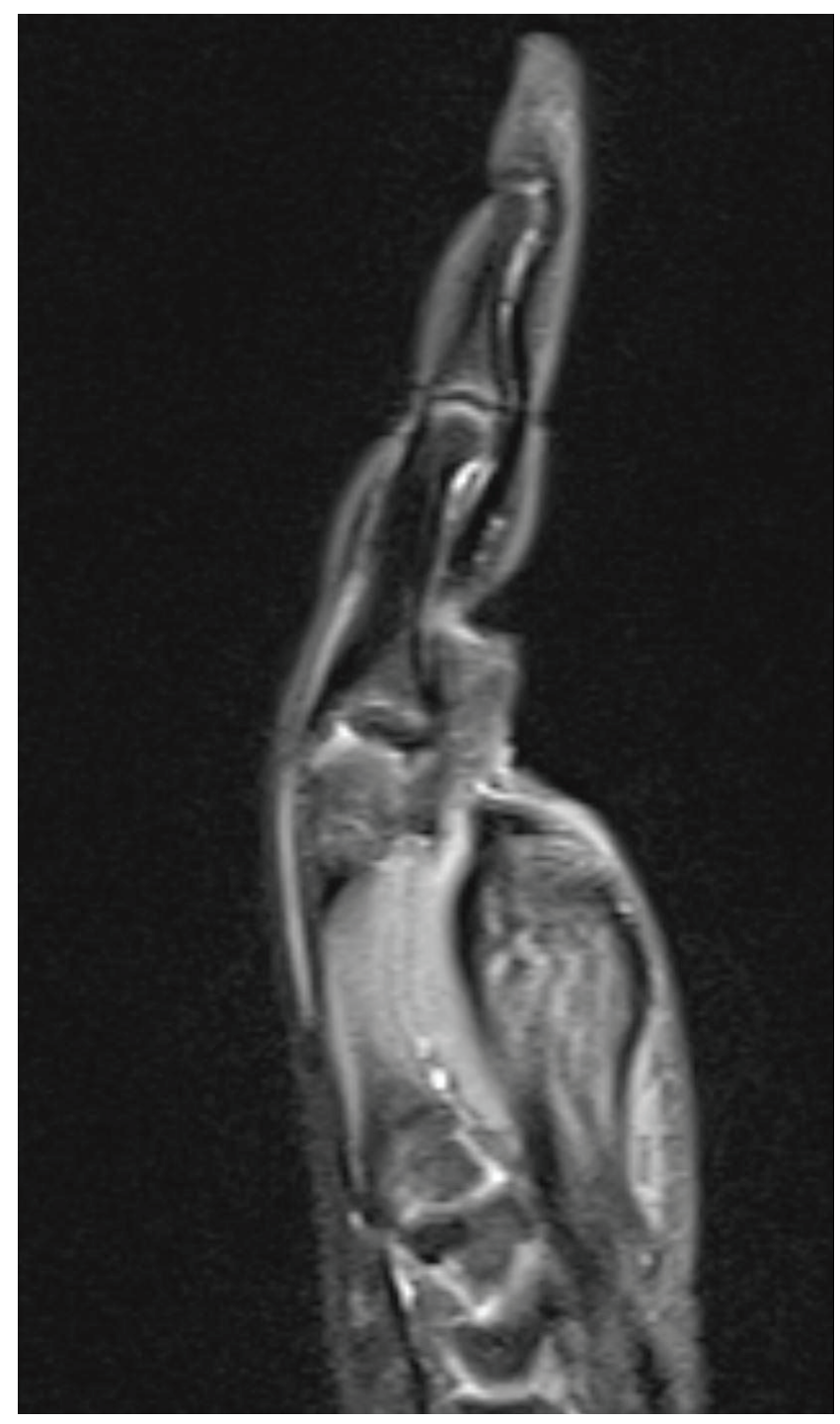

Figure 1c. Pd TSE fat saturated sagittal image shows hyperintense nerve bundles surrounded by hypointense fibrofatty tissue.

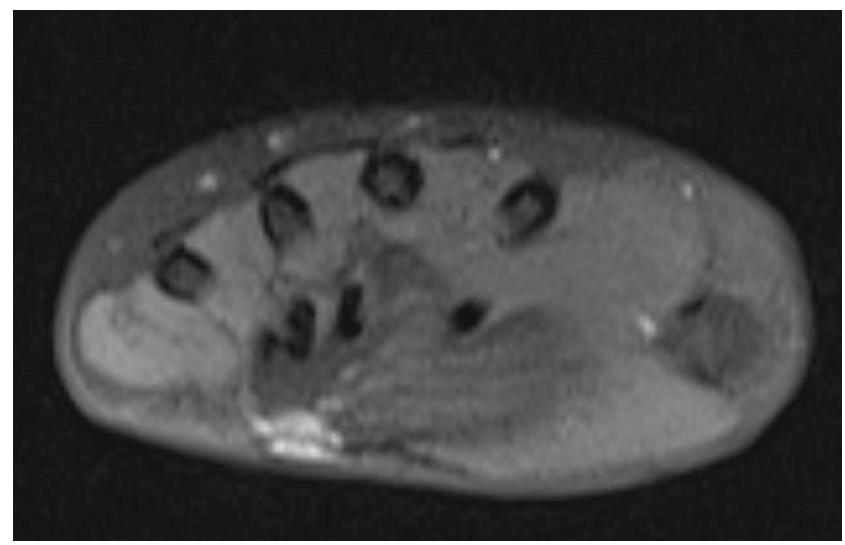

Figure 2a. T1 TSE axial fat saturated pre-contrast image. 


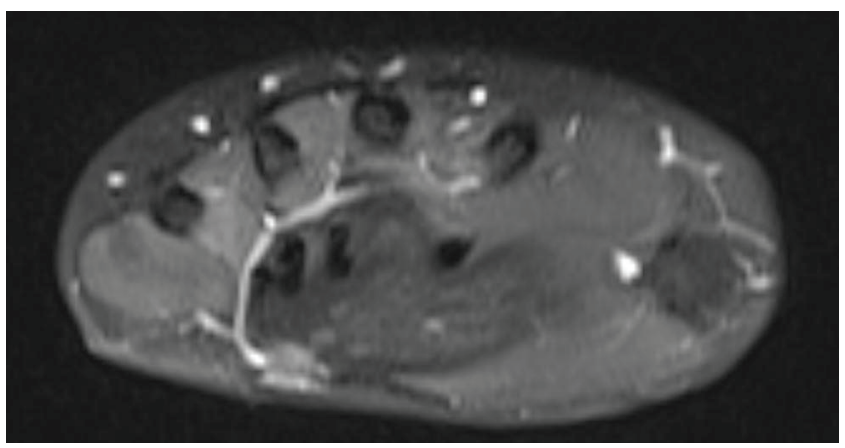

Figure 2b. T1 TSE fat saturated post-contrast image reveals that the lesion shows no enhancement.

US examination showed a $75 \times 35 \mathrm{~mm}$ lesion composed of echogenic fat tissue and hypoechoic, thickened nerve fibers. The lesion extended to the distal forearm. Nerve fibers had the classical "co-axial cable like appearance" on axial US images, as well. On Doppler examination the lesion was hypovascular and there was only minimal intralesional blood flow (Figure 3a,b,c).

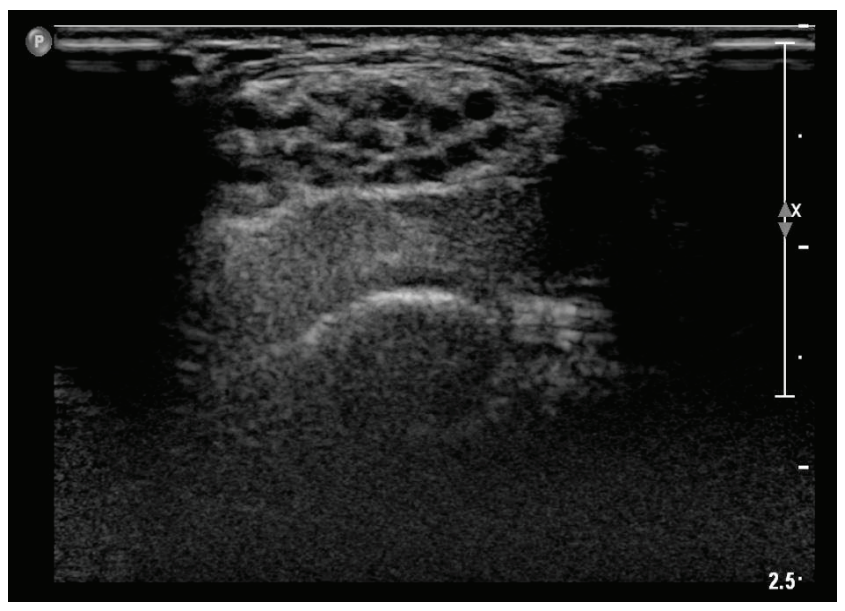

Figure 3a. Axial US images reveal round hypoechoic nerve bundles surrounded by hyperechoic fat.

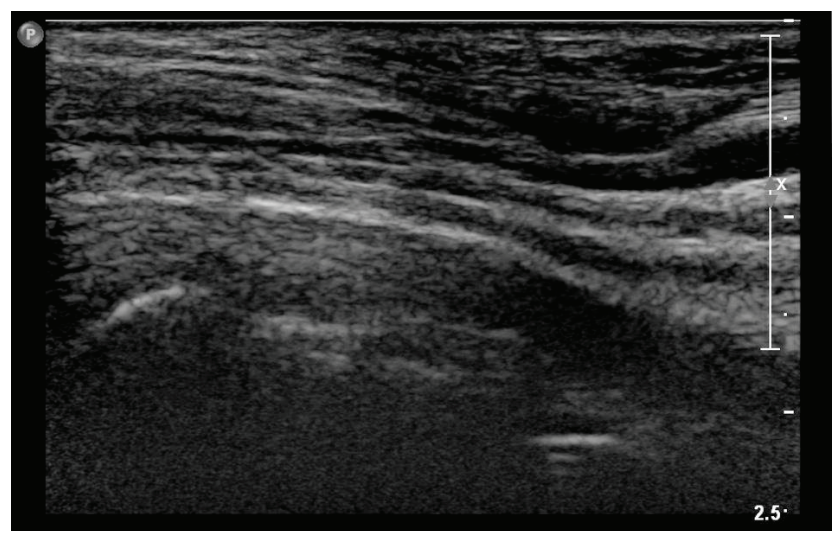

Figure 3b. Longitudinal US image reveals round hypoechoic nerve bundles surrounded by hyperechoic fat and extension to distal forearm.

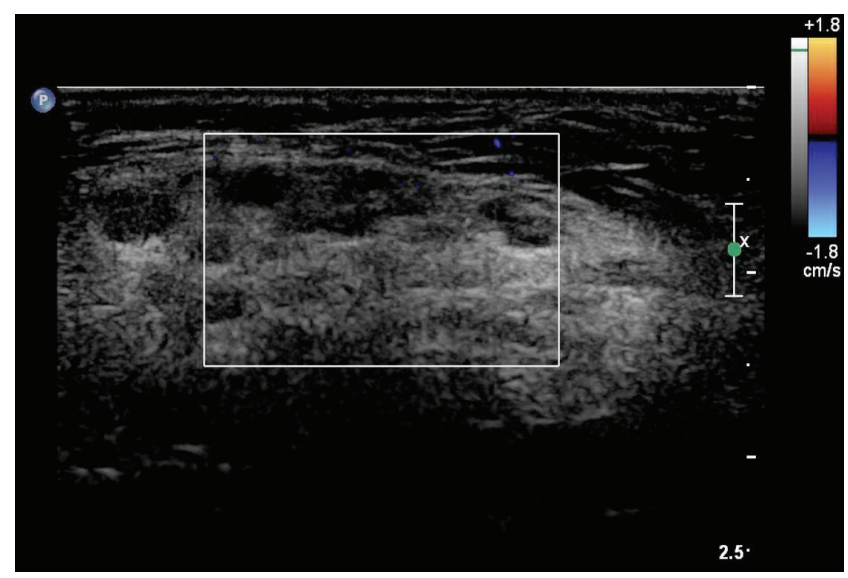

Figure 3c. Doppler US shows no evident blood flow.

Diagnosis was made with MRI and US findings, biopsy was not performed. Since it is a benign condition and patient did not have median nerve compression findings or macrodactyly, surgery was not performed in our case.

\section{Discussion}

Two percent of all upper extremity tumors are nerve tumors. Schwannoma is probably the most common diagnosis. Usually, diagnosis of nerve tumors is based on histopathologic findings. In contrast, lipomatosis of nerve has characteristic MRI findings [1].

Lipomatosis of nerve was first described by Mason in 1953 [2]. Johnson and Bonfigilo introduced the term lipofibromatous hamartoma [3]. In 2002, the World Health Organization adopted the term lipomatosis of nerve [4]. To date, there are several terms used to describe this condition including fibrolipomatous hamartoma, intraneural hamartoma, neural fibrolipomatosis and neural fibrolipoma [5].

Lipomatosis of the nerve is a rare, congenital, benign tumor consisting fibrofatty proliferation within peripheral nerves with unknown etiology. Hypertrophy of fat and fibroblasts in the epineurium results in enlargement of the involved nerve. The median nerve is the one most commonly affected, followed by the ulnar and radial nerves, the brachial plexus and cranial nerves [6].

Most common presentation of lipomatosis of nerve is a swelling or mass on the volar aspect of the wrist or distal forearm. Patients present mostly during childhood and the chief complaint is a painless mass. The mass usually appears years before neurologic symptoms since it grows slowly. Associated clinical symptoms are pain, numbness, 
motor and sensory deficits in the median nerve distribution caused by compression of median nerve in the carpal tunnel [7]. Guthikonda et al., classified lipid-containing neural masses according to relation with parent nerve. Soft tissue lipoma, lipomatosis of nerve, intraneural lipoma and macrodystrophia lipomatosis are included to this classification. Soft tissue lipomas are easily differentiated as they are located outside the nerve and does not contain any neural proliferation. Intraneural lipomas are focal lipid masses which are separate from nerve bundles [8]. Macrodactyly is seen in \%27-67 patients and has been referred to as macrodystrophia lipomatosa [9-11]. Other causes of macrodactyly are neurofibromatosis type 1 , Proteus syndrome and Klippel-Trenaunay-Weber syndrome.

US and MRI examination of these lesions are pathognomonic and usually diagnosis can be made without a biopsy. US examination reveals round hypoechoic nerve bundles surrounded by hyperechoic fat. Long axis examination shows the "spaghetti like" appearance and on the axial plane a "co-axial cable like" appearance is seen. Color Doppler US shows no evident blood flow within the lesion. MRI reveals fusiform enlargement of the nerve containing thickened axonal bundles encased in epineural fibrous tissue giving again the "co-axial cable like" appearance on axial images and "spaghetti like" appearance on coronal images [12]. The lesions do not enhance with IV contrast material.

US revealed hypoechoic nerve bundles surrounded by fat tissue without evident blood flow in our case. The extension of the lesion to the forearm was also assessed with US imaging. MRI showed spaghetti like and co-axial cable like appearences and in proton density fat-saturated sequences showed hyperintense nerve bundles surrounded by hypointense fibrofatty tissue. All of the imaging findings in this case were consistent with the literature.

Histopathologic examination reveals fatty infiltration separating nerve bundles.

Treatment is mostly conservative. Surgery may be performed in symptomatic patients for decompression and amputation may sometimes be necessary for macrodactyly.

\section{Acknowledgements}

Disclosure: The authors declare no conflict of interest.

\section{References}

1. Nilsson J, Sandberg K, Dahlin LB, et al. Fibrolipomatous hamartoma in the median nerve in the arm - an unusual location but with MR imaging characteristics: a case report. J Brachial Plex Peripher Nerve Inj 2010;5:1. doi: 10.1186/1749-7221-5-1

2. Mason M. Presentation of cases. In: Proceedings of the American Society for Surgery of the Hand, 1953. J Bone Joint Surg Am 1953; 35A:273-5.

3. Johnson RJ, Bonfigilio M. Lipofibromatous hamartoma of the median nerve. J Bone Joint Surg 1969;51:984-90.

4. Christopher D, Unni K, Mertens F. Adipocytic tumors. In: Fletcher CDM, Unni K Mertens F, editors. WHO Classification of tumors. Pathology and genetics: tumors of soft tissue and bone. IARC 2002; 19-46.

5. Julien TP. Lipofibromatous hamartoma: A review article. OHJMS 2009;11:87-90.

6. Kransdorf M, Murphey M. Lipomatous tumors. Imaging of soft tissue tumors. Philadelphia: Pa: Saunders, 1997; 57-101.

7. Louaste J, Zejjari H, Chkoura M, Houmadi A, Rachid $\mathrm{K}$ : Carpal tunnel syndrome due to fibrolipomatous hamartoma of the median nerve. Hand (N Y) 2011;6:76-9. doi: 10.1007/ s11552-010-9290-8

8. Guthikonda M, Rengachary SS, Balko MG, van Loveren H. Lipofibromatous hamartoma of the median nerve: Case report with magnetic resonance imaging correlation. Neurosurgery 1994;35:127-32.

9. Chiang CL, Tsai MY, Chen CK. MRI diagnosis of fibrolipomatous hamartoma of the median nerve and associated macrodystrophia lipomatosa. J Chin Med Assoc 2010;73:499-502. doi: 10.1016/S1726-4901(10)70107-6.

10. Silverman TA, Enzinger FM. Fibrolipomatous hamartoma of nerve: a clinicopathologic analysis of 26 cases. Am J Surg Pathol 1985;9:7-14.

11. Azeemuddin M, Waheed AA, Khan N, Sayani R, Ahmed A. Fibrolipomatous hamartoma of the median nerve with macrodystrophia lipomatosa. Cureus 2018;10:e2293. doi:10.7759/cureus.2293.

12. Toms AP, Anastakis D, Bleakney RR, et al. Lipofibromatous hamartoma of the upper extremity: a review of the radiologic findings for 15 patients. AJR Am J Roentgenol 2006;186:805-11. doi:10.2214/AJR.04.1717 